\title{
Writing in the Anthropocene: Idle Chatter or Ecoprophetic Witness? KATE RIGBY
}

A book must be the ax for the frozen sea within us.

Franz Kafka

We must regenerate ourselves if we are to regenerate the earth. ... Our feelings and emotions must be engaged, and engaged on a large scale.

Judith Wright

Two words haunt any ecologically attuned consideration of the historical hour in which our increasingly globalised world currently finds itself: one, which heads this special issue of the Ecological Humanities, is 'anthropocene'; the other, lurking as a grim potential, or even an unfolding reality, within the notion of the anthropocene is 'ecocide'. The former term implicates us all in a call to responsibility: the future of Earth, understood as a diverse collectivity of more-than-human life and the conditions in which such life either thrives or fails, we are told, now lies in our human, all-too-human hands. Awesome, and certainly burdensome, though the responsibility connoted by this word may be, the latter term is more troubling, implicating us, and some considerably more than others, as perpetrators of a crime against our Earth others that is at once historically unprecedented and morally unforgivable, and by which we too are now imperiled. Thinking these two terms in conjunction, we are confronted by the question of whether the anthropocene will be the era in which the ecocidal violence that modern industrial civilization has thus far unleashed upon the Earth will culminate in the utter destruction of humanity's planetary birthplace, the oikos that remains still our only home and the home of the myriad other beings who are our kin; or whether we will manage to pull back from the brink, vouchsafing our Earth others the possibility not merely of a continued existence after their own kind, but perhaps even of a renewed and greater flourishing, as those of our kind, who had come to consider themselves apart from and above the rest, learn to live in a more just and compassionate pattern of relationship with the more-than-human lives in whose midst, and through whose grace, we ourselves exist.

In this article, I want to make a case for the value of writing in the anthropocene in the mode of prophetic witness. Such writing would seek to disclose the catastrophic consequences of continuing on our current ecocidal path and 
awaken us to the possibility of another way of thinking and being: one that holds the promise of reconciling urban industrial society with the Earth. The model of prophetic witness that I call upon here is biblical, but I am going to bring it to bear in an ecocritical rereading of a work of modern secular literature: Judith Wright's 'Dust', a poem penned during the Second World War that has acquired a whole new salience in the era of anthropogenic climate change. Before I get there, though, I want to dwell for a moment on the difficulties of this undertaking, and especially the risk that, in the face of the unspeakable horror of an unfolding ecocide, all our fine words might amount to little more than 'idle chatter'. ${ }^{1}$

It is Theodor Adorno who alerts us to this possibility in writing on the crisis of art in the wake of the Shoah. Let me cite the whole passage from 'Cultural Criticism and Society' from which the well-known (and generally misrepresented dictum) on 'poetry after Auschwitz' is taken:

The more total society becomes, the greater the reification of the mind and the more paradoxical its attempt to escape reification on its own. Even the most extreme consciousness of doom threatens to degenerate into idle chatter. Cultural criticism finds itself faced with the final stage of the dialectic of culture and barbarism. To write poetry after Auschwitz is barbaric. And this corrodes even the knowledge of why it has become impossible to write poetry today. (Prisms 34)

Read in its wider argumentative context, Adorno is not announcing the end of poetry per se here. Rather, he is insisting that if it is not to 'degenerate into idle chatter,' literature, along with other forms of art, needs to acknowledge its own failure, both to prevent the unspeakable horror of the Nazi extermination camps and adequately to respond to it in an aesthetic medium. As Elaine Martin has recently argued, Adorno

calls for a form of art, which bears witness to its predestined failure, artworks which present the fact that the 'unrepresentable' exists. Adorno's dialectic emphasizes the indispensability of that which it simultaneously deems impossible, it demands the pursuit of that which it deems futile. (11)

If, in George Steiner's words, the Shoah confronted humanists with the devastating realisation that 'a man can read Goethe or Rilke in the evening [...] and go to his day's work at Auschwitz in the morning' (ix) so too, ecocritics

\footnotetext{
1 Many thanks to the two anonymous reviewers of this article, whose thoughtful comments and suggestions have been invaluable in helping me to clarify my argument at various points. Needless to say, the remaining infelicities are entirely my own. I am also grateful to the Australian Research Council for providing funding for the research project 'Imagining the Great South Land' from which, in part, this article arises.
} 
must acknowledge that a woman might well read Wordsworth or Thoreau in the evening (well, in the unlikely event that she has any time for reading at all), and go to her day's work for Exxon-Mobil in the morning-and, for that matter, I would not be at all surprised to encounter a Japanese whaling executive with a taste for Basho. And yet, for all that, this of all times is no time to withhold our poetic words from the more-than-human world. We might have grown wary of that hoary old metaphysical abstraction, 'nature,' an invention of settler civilisations unknown to hunter-gatherer societies, which, as Plumwood suggested some years ago, we would be able to dispense with altogether in a fully ecological culture (Plumwood, 'Nature as Agency'): but the plight of Earth's waters, forests, soils and atmosphere, and of those myriad creatures, human and otherwise, whose life depends upon them, obliges us to utterance, even though we know that our words, no matter how artfully wrought, are bound to be insufficient either to prevent or to bespeak the unprecedented horror of the ecocide of which we ourselves are both victims and perpetrators.

Now, this is tricky territory, so let me attempt to clarify what I am saying here. I certainly do not want to equate the Nazi genocide of the Second World War with the largely unintentional ecocide that looms before us today. Leaving aside for the moment localised exterminations of competitor species, such as the wolf in much of Europe and North America, the mass extinction event in which we now find ourselves appears to constitute something more like collateral damage, an accidental by-product of the industrialisation of the Earth, now almost exclusively under the aegis of an aggressively globalising, if currently rather crest-fallen, capitalism. Yet the relative unconcern - the refusal to witnesswith which the fate of non-human others is generally regarded, notwithstanding the efforts of individuals and minority groups, whether that fate is traced in the extinction of whole species or in the day-to-day suffering and death of animals in the meat trade, in laboratories, in recreational hunting, or simply on our blood-spattered roads, holds a clue as to the structural connection-but not, I repeat, equivalence - between genocide and ecocide.

This clue pertains the to what poststructuralists term the logic of the Same, or, in Plumwood's terms, the 'logic of colonisation' (Feminism) or of 'centrism' (Environmental Culture), which, in instituting a rigid divide between subject and object, self and other, denies ethical considerability to anyone, or any thing, that is excluded from the company of the sovereign self. Relegated to the realm of mere materiality as opposed to privileged sphere of mind, spirit or reason, animals have long been in the front-line of the domination of nature. ${ }^{2}$ Indeed,

2 In Problems of Moral Philosophy, Adorno says of Schopenhauer's critique of Kantian Idealism that he 'probably suspected that the establishment of total rationality as the supreme object principle of mankind might well spell the continuation of that blind domination of nature whose most obvious and tangible expression was to be found in the exploitation and maltreatment of animals' (215). 
within idealist thought, as Adorno once observed, 'animals play virtually the same role that the Jews played for the fascist system' (Beethoven 123). In that sense one might well say that, 'Auschwitz begins whenever someone looks at a slaughterhouse and thinks: they're only animals'. ${ }^{3}$

It is, of course, as a response to Auschwitz, and the annihilatory logic that helped to make it possible, that the thinking of alterity acquires its ethicopolitical urgency in the contemporary thought of Emmanuel Levinas, among others. Yet in restricting ethical response and responsibility to the human other, in whose face and speech alone we are called to account, Levinas's ultimately 'anthropologocentric' project, as Silvia Benso terms it, perpetuates aspects of the negative structure that it seeks to overcome (Benso 136). The lesson of Auschwitz runs deeper, and demands more of us, than most major continental philosophers (with the exception Derrida ${ }^{4}$ and, before him, Adorno) have yet realized. Bringing down the divide that allows certain human groups to be categorised as available for use, abuse and potential annihilation is not enough. The hyperseparation that segregates the human other from other others, as ecophilosophers have long argued, ${ }^{5}$ must also be called into question. Now that we are being forced to recognise the ecocidal, as well as genocidal, implications of the logic of the Same, we are called to extend our thinking of alterity in the direction of an ecological ethics, in which we are accountable to more than only human others. This constitutes one of the central challenges of the anthropocene, not only for philosophy, but also for literature and other forms of art.

Before I turn to a further consideration of this challenge with respect to writing specifically, it is necessary to register another apparent difference between the genocidal violence connoted metonymically by the name of Auschwitz, and the ecocidal violence of the present: namely, the fact that the latter is as yet incomplete, remaining in potentia, as a possible future horizon, rather than a catastrophe that had already come to pass. So, whereas Adorno was concerned with the plight of poetry 'after Auschwitz', our concern is with how to write in the midst of an unfolding disaster, the catastrophic culmination could perhaps yet be forestalled. This is not to say, however, that genocide is a thing of the past: far from it. Moreover, genocide and ecocide are not infrequently entangled, not only in theory, as suggested above, but also in historical practice, above all in

3 Translation of 'Auschwitz beginnt da, wo jemand auf Schlachthof steht und denkt: Es sind ja nur Tiere', attributed to Adorno in Blanke (48), but as I have not been able to track down the source of this quote (widely cited in animal liberation literature), it could be apocryphal. On the ethics of animals in Adorno, see Savage; Gerhardt.

4 See especially The Animal That Therefore I Am.

5 Among the first to do so, at opposite ends of the world, were the Norwegian philosopher Arne Naess (1973) and the Australian philosophers, Val and Richard Routley (1973 and 1979), later Val Plumwood and Richard Sylvan. Perhaps the most fully elaborated ecophilosophical critique of anthropologocentrism (or the 'logic of colonisation') is to be found in Plumwood, Environmental Culture. 
the context of colonisation. As Deborah Rose puts it, settler societies 'are built on a dual war: a war against Nature and a war against the natives' (Reports 34). In Australia, the devastating legacy of this dual war includes:

the loss of around 90 per cent of the original Aboriginal population, the loss of all but a small number of Aboriginal languages, and the loss of earlier cultural coherence of the continent through Aboriginal networks of cultural exchange. It includes the loss of large numbers of plant and animal species, including the highest rate of mammalian extinctions in the contemporary world [...] the regular loss of topsoil [...] large amounts of agricultural land [...] to salinity [and] of pastoral land [...] to erosion and scalding. (Rose, Reports 35-6)

In view of the geographical and social stratification of the impacts of climate change, whereby many of the most vulnerable communities and peoples, such as those of Bangladesh and several Pacific Island nations, are among those least responsible for the carbon emissions currently warming our planet, we might well need to reckon with new kinds of entanglement between ecocide and genocide.

In my earlier work on literature and ecology, I have argued for a form of 'negative ecopoetics' which sings the praises of the living Earth in an aesthetic frame that acknowledges the impossibility of capturing its phenomenality in writing, or even of responding entirely adequately to its call ('Earth'; 'Writing'). Such writing, in Mary Oliver's words, 'would put all its money on the power of suggestion' (53), enticing us to lay aside our reading and seek out the kinds of embodied experience of the living Earth that might strengthen us in our desire to defend our Earth others, human and otherwise, against the forces of injustice and destruction - a desire whose fulfilment nonetheless necessarily returns us once more to the world of words (which, in truth, we have never truly or wholly left behind). Here, I want to turn my attention towards another mode of ecopoetic negativity; one that is concerned less with praise than critique, leaning more towards lamentation than celebration. Here, I take my cue, not from Mary Oliver, but from Franz Kafka, who once declared in a letter to his friend Oskar Pollak:

I think we ought to read only books that bite and sting us. If the book we are reading doesn't shake us awake like a blow to the skull, why bother reading it in the first place? So it can make us happy? Good God, we'd be just as happy if we had no books at all [...] A book must be the ax for the frozen sea within us. (36)

Kafka's drastic, not to say violent imagery, recalls the voice of the Hebrew prophets, whose language of lamentation and forewarning was pitched at 
breaking through the psychic numbness engendered by what biblical scholar Walter Brueggeman (2001) terms 'royal consciousness': a way of thinking and being that renders us insouciant towards suffering, heedless of injustice, content with affluence, and dangerously unaware of our own imperilment. Writing in the anthropocene, it is precisely such biting, stinging words of prophetic imagination that might just be able to prevent our concern about ecocide from degenerating into 'idle chatter'.

According to the Jewish philosopher Martin Buber (in whose journal Der Jude, incidentally, Kafka's devastating critique of human racism, 'A Report to an Academy', was first published in October 1917), the ancient Hebrew prophetic tradition, which was carried forward into the Christian Gospels in the ministry of Jesus of Nazareth, differs from both Jewish and Christian apocalyptic writing of the late Hellenic period in the position that it assumes towards 'the historical hour'. While apocalyptic shares with prophetic the revelation that humans, for all their self-proclaimed apartness, belong ultimately to a more-than-human community of fate, it tends to constitute history as pre-determined in its outcome, leaving human agents little option other than to prepare themselves for the millennial end that heralds a glorious new beginning. By contrast, the prophetic voice insists on the ever-present possibility of a change in direction in the present, in the absence of which there is absolutely no promise of redemption. As Terry Eagleton puts it, '[t]he role of the prophet is not to predict the future, but to remind the people that if they carry on as they are doing, the future will be exceedingly bleak' (175).

The central trope of prophetic writing, in Buber's analysis, is that of turning and returning, on the part of both the people and their God, whose relationship is conceived as dialogical. The prophetic voice, moreover, while understood as uttering the speech of heaven, does not speak from a place of purity: the prophet is both implicated in and wounded by the wrongdoing that is shown to be driving his or her world headlong into catastrophe. 'There is in the prophetic voice,' writes Deborah Rose, citing Susan Handelman, 'an 'ethical self-exposure' in which subjectivity lays bare its vulnerability, and opens itself consciously to others' ('On history', 165). Prophetic speech is inspired by the imaginative capacity to see through and beyond those conventional attitudes, assumptions and patterns of behaviour that engender or support oppression and wrongdoing; and it is propelled by the hunger for justice, underpinned by compassion, that cannot tolerate complacency in the face of another's suffering. Breaching the fortress of royal consciousness, the mindset of mastery and privilege that renders us insouciant to the suffering of others and unmindful of our own vulnerability, the prophet speaks with the voice of grief; but also, 
implicitly or explicitly, of hope. Prophetic speech incites lamentation in order to engender transformation, at the same time that it warns of what will ensue if the people fail to heed the call.

In a recent presentation at the Two Fires Festival of Arts and Activism in Braidwood (March 2009), I discussed a poem by Judith Wright, in whose honour this festival was founded, as an exemplary work of 'ecoprophetic' witness, and I would like to conclude this article by returning to that discussion of Wright's biting and stinging lyric, 'Dust' (Collected Poems, 23-4): ${ }^{6}$

This sick dust, spiraling with the wind, is harsh as grief's taste in our mouths and has eclipsed the small sun.

The remnant earth turns evil, the steel-shocked earth has turned against the plough and runs with wind all day, and all night sighs in our sleep against the windowpane.

Wind was kinder once, carrying cloud like a waterbag on his shoulder; sun was kinder, hardening the good wheat brown as a strong man. Earth was kinder, suffering fire and plough, breeding the unaccustomed harvest. Leaning in our doorway together watching the birdcloud shadows, the fleetwing windshadows travel our clean wheat we thought ourselves rich already.

We counted the beautiful money and gave it in our hearts to the child asleep, who must never break his body against the plough and the stubborn rock and tree.

But the wind rises; but the earth rises, running like an evil river; but the sun grows small, and when we turn to each other, our eyes are dust and our words dust.

Dust has overtaken our dreams that were wider and richer than wheat under the sun, and war's eroding gale scatters our sons with a million other grains of dust.

6 A number of ecocritical discussions of Wright's work have appeared over the past decade, including 'An Ecological Vision: Judith Wright' in Bennett; Zeller; Kohn; Brady, Kutchins, Rees and Sharp in a special section of LocalGlobal (Volume 3, 2007) on the legacy of Judith Wright; and Gifford. I had also discussed this poem from another perspective at an earlier Two Fires Festival, and I am very grateful to my interlocutors on that occasion, especially Terry Gifford and Stuart Cooke, for their comments on the earlier version. 
O sighing at the blistered door, darkening the evening star, the dust accuses. Our dream was the wrong dream, our strength was the wrong strength.

Weary as we are, we must make a new choice, a choice more difficult than resignation, more urgent than our desire of rest at the end of the day. We must prepare the land for a difficult sowing, a long and hazardous growth of a strange bread, that our son's sons may harvest and be fed. ${ }^{7}$

Although Wright did not consider herself to be a Christian, or any other kind of theist for that matter, her poetry is profoundly indebted to biblical imagery (just as her politics clearly owed much to the core biblical values of justice and compassion). In the case of 'Dust,' a poem that she penned in the war-torn, drought-ridden summer of 1942-3 (Brady, South 91), it is possible to discern an echo of one particular prophetic motif, namely that of the drying up or mourning of the land (the Hebrew verb used in these biblical passages can mean both desiccation and grief). In the Hebrew Bible, the dialogical relationship between people and God is nearly always triangulated by the figure of the land or earth (erets), and in the Book of Jeremiah, it is the grieving earth itself that is said to bear the brunt, and thereby also mark the measure, of human wrong-doing. In the drying up of the land and in the dying of their fellow creatures, on the land and sometimes also in the sea, ${ }^{8}$ the people stand accused of breaking their covenant with God: 'because of this,' we read in Jeremiah 4:28, 'the earth will mourn/dry up, and the heavens above become dark' (translated Val Billingham ${ }^{9}$ ). Admittedly, in such biblical texts it is generally unclear as to whether the land has itself been wronged, or whether its drought-ridden state has been wrought by YHWH purely in order to punish the people who depend upon its bounty. In at least one passage in Jeremiah, however, it appears that the desolation of the land is indeed a direct result of a human wrongdoing, in the guise, moreover, of a failure to cherish it: in the King James translation of

\footnotetext{
7 I am grateful to Wright's publisher, HarperCollins, for allowing me to quote this poem in full in this article. 8 E.g. Hosea 4:3 reads 'Therefore shall the land mourn, and every one that dwelleth therein shall languish, with the beasts of the field, and with the fowls of heaven; yea, the fishes of the sea shall also be taken away' (Holy Bible, King James Version); or, in the New Revised Standard Version of The Green Bible (the publication of which is in itself a sign of hope, insofar as the 'greening' of Christianity, along with many other faiths, both new and old, could play a part in pulling the global community back from the brink): 'Therefore the land mourns, and all who live in it languish; together with the wild animals and the birds of the air, even the fish of the sea are perishing'.

9 I am grateful to Val Billingham, a graduate student at the Melbourne College of Divinity, for alerting me to the significance of this figure in Jeremiah, and for pointing out that the Hebrew word commonly translated as 'mourns' can also mean 'dry up'. I am even more indebted to my own DMin student at the Melbourne College of Divinity, Janet Morgan, for introducing me to the work of Brueggeman and for conceptualizing the ecoprophetic voice. Jan's thesis is entitled 'Earth's Cry'. For a more historical discussion of the Hebrew prophets, see Heschel.
} 
Jeremiah 12:11, YHWH says of the land through the voice of the prophet: 'They have made it desolate, and being desolate it mourneth unto me; the whole land is made desolate, because no man layeth it to heart ${ }^{\prime} .{ }^{10}$

The prophetic voice is called forth by the cry of the oppressed, and in Jeremiah, it is the earth itself that calls out, communicating its distress in desiccation. And so it is too in Wright's ecoprophetic poem, 'Dust'. The cry, which the prophet apprehends and mediates, is an indication that something is drastically wrong. The speaker of Wright's poem, who hears the earth sighing all night 'against the windowpane,' if only in sleep, and so perhaps unconsciously, initially locates the source of the wrong in the land itself: 'The remnant earth turns evil,' laments the dismayed farming woman whose address we hear in this poem. In the very next line, however, we are given a hint that the land might actually be the victim rather than the agent of this wrong, for the earth that 'has turned against the plough' is said to have been 'steel-shocked'. Later in the poem, as the speaker moves towards a revised assessment of what is amiss, a metaphoric association is drawn between the loss of topsoil from the ploughed land in the drought and the deaths of men on the battlefields of the war; men, who are identified emotively from the maternal perspective of the speaker as 'sons': 'and war's eroding gale scatters our sons/with a million other grains of dust'. In light of this linkage, we might hear in 'steel-shocked' an echo of the World War One expression 'shell-shocked,' and in this echo, a suggestion that the agricultural landscape is itself a battle-field of sorts. ${ }^{11}$

This is not how the speaker initially speaks of the land, though, in recalling happier times: 'Wind was kinder once, carrying cloud/like a waterbag on his shoulder; sun was kinder,/hardening the good wheat brown as a strong man'. Yet once again in the following lines there are hints that this 'kindness,' that is to say, the amenability of the land to the production of wheat, was not so much gifted as extorted: 'Earth was kinder, suffering fire and plough,/breeding the unaccustomed harvest' (my italics). Here, the connotations of 'steel-shocked' are reinforced, and we are reminded that the earth that was now 'running with the wind' had once been accustomed to a very different kind of treatment: indeed, as Wright would later come to recognize, a kinder treatment, namely from those Indigenous landholders from whom the speaker's people (who were also, of course, the poet's ${ }^{12}$ ) had stolen it.

\footnotetext{
10 Biblical scholars will hasten to point out that this is not necessarily a particularly accurate translation: the currently most authoritative version, reads 'They have made it a desolation; desolate, it mourns to me. The whole land is made desolate,/but no one lays it to heart' (The Green Bible). It is the King James Version of the Bible that is of most interest to literary scholars, however, both as a canonical text in its own right and as an influential intertext for the work of English-speaking artists and writers.

11 For a recent discussion of this common motif in Australian settler culture, see Robin 2009.

12 See especially Wright, Cry of the Dead and Born of Conquerors.
} 
If, at first, the speaker mistakenly perceives the wrong that she intuits as arising from, rather being suffered by, the land, it is because she is still blinkered by dominant ways of thinking, and in particular by that thinking which legitimates human domination of the earth (along with settler domination of colonized peoples and an array of other social hierarchies). Wright's later acquaintance, the feminist ecophilosopher Val Plumwood, referred to this dualistic and hierarchical way of thinking as the 'standpoint of mastery'. In 'Dust', such a standpoint is implicit in the speaker's recollection of her former aspirations with respect to the land: 'Leaning in our doorway together/watching the birdcloud shadows,/ the fleetwing windshadows travel our clean wheat/we thought ourselves rich already'. Claimed as private property, the colonized earth is valued primarily as a source of economic wealth and a vehicle of upward social mobility, by means of which the speaker and her husband had hoped to free their son from rural labour, which is now construed explicitly as entailing considerable struggle with a recalcitrant land: 'We counted the beautiful money/and gave it in our hearts to the child asleep,/who must never break his body/against the plough and the stubborn rock and tree'. While the speaker claims our sympathy here for the hardship that she and her people have suffered in pursuit of a dream that is now being dashed both by the war that is claiming their sons' lives and by the drought that is ruining their harvest, it is made clear that their calculation of future happiness is founded on the standpoint of mastery, resting as it does upon the assumption that they would ultimately claim victory in their battle with the land (the unspoken battle for the land evidently being assumed to have been won already).

In reducing Earth to the status of a mere resource under human sway we become insouciant to other-than-human suffering. Just as royal consciousness silences the cry of oppressed peoples, the standpoint of human mastery silences Earth's cry. What this poem traces is the moment when such silencing mechanisms begin to break down: 'But the wind rises; but the earth rises,/running like an evil river; but the sun grows small,/and when we turn to each other, our eyes are dust/and our words dust'. In the opening stanza, the dust was described as 'harsh as grief's taste in our mouth,' a simile that creates an association between the harshness of the desiccated land and the harshness of the grief felt by the speaker for her own loss, while implying that the association is that of cause and effect: the speaker grieves because the remnant earth, as she puts it, has 'turned evil'. Here, once again, evil is seen to be manifest in the land, as the dust runs 'like an evil river' in place of the waterways that have run dry. Now, though, the earlier simile has been displaced by a more intimate metaphoric association between the human subject and the dessicated soil; one that intimates a dawning realization that it is not only the land that is eroding, but the perspective from which her people had hitherto viewed and spoken of it: 'our eyes are dust/and our words dust'. As the standpoint of mastery begins to crumble, it becomes 
apparent that in its drying out, the land too is calling out in grief, and the speaker is forced to recognize her own culpability in the wrong to which the dust bears witness: 'O sighing at the blistered door, darkening the evening star,/ the dust accuses'.

Grieving now not for herself alone, but with and for the wider Earth community, human and otherwise, that she and her kind have wronged, the speaker is finally forced to admit that, 'Our dream was the wrong dream,/our strength was the wrong strength'. This recognition has come too late to avert disaster. Yet, in keeping with the biblical tradition upon which Wright draws at the same time that she departs from it, there remains the possibility of going forward otherwise, incorporating a new covenant, if not with God, then with Earth itself.

In the final lines of the poem, addressed to a community yet to come, 'land' bears a double burden of meaning: that which must be prepared 'for a difficult sowing' is not only the land that demands to be farmed otherwise, farmed that is, with a view to making a living with rather than from it; it is also the self that requires to be thought otherwise, such that (recalling the Parable of the Sower from Matthew 13: 24-30), 'sowing' might be read as the imparting of a truth that not all, perhaps, will be ready, willing or able to receive. Similarly, the recollection of the Eucharistic feast carried by 'bread' suggests that what is at issue here is the soul no less than the soil: the anticipated 'bread' might then be understood not only as a source of nourishment, but as a sacrament of sorts, seeded by the poetic word in its radical critique of royal consciousness. The possibility of reconciliation that is proffered at the end of this ecoprophetic verse is nonetheless not conventionally Christian, the qualifier 'strange' prefiguring the necessary emergence of 'new relationships and forms of thought not yet realized,' as Wright later put it in her essay 'The Writer and the Crisis' (1952). ${ }^{13}$ In this way, 'Dust' calls upon its readers to have the courage to surrender familiar patterns of thinking and being in favour of cultivating a different sense of self, incorporating a more life-sustaining way of being-in-relationship, not so much with a God beyond, but with one another and with the land: only thus might the flourishing of future generations be assured. ${ }^{14}$

Although it was written over half a century ago, I believe that this poem speaks powerfully to our present historical moment of eco-climatic imperilment. Today, wars that will increasingly be fought over Earth's dwindling 'resources' threaten

13 Here, Wright uses the metaphor of 'bread' with specific reference to language, understood as 'the vast symbol of man's relationship to the universe [...] It is at once the bread he lives by, and the seed wheat from which will come the bread of future generations, for in it lie potential new relationships and forms of thought not yet realized' (Because 175).

14 For a socio-economic perspective on what such a transformation might look like, see e.g. Gerda Roelvink and J. K. Gibson-Graham (2009). 
to proliferate, 'scattering our sons with a million other grains of dust'. Today, too, 'the dust accuses,' not only on the drying agricultural land of southeastern Australia, but on a planetary scale: the dust accuses, for instance, when it blows from the parched plains of sub-Saharan Africa, where the monsoon has failed yet again on account of the polluted atmosphere of Europe, and, crossing the Atlantic, enters the lungs of children in the Caribbean, who sicken with asthma, for which only the wealthy can afford medicine (Schmidt). Now, moreover, it is also the wind that accuses, and never more so than when the cyclonic storms and rising seas cooked up by we who feed on fossil fuels bear down upon the poor of far lower carbon-emitting climes.

We need the help of scientists, both natural and social, to disclose such ills, and the engagement of activists, politicians and policy makers to redress them. But if we remain walled in behind the battlements of royal consciousness, we shall be ill-prepared to make not only the effort, but, let's face it, the sacrifice, that would be necessary to right such wrongs and forestall major planetary catastrophe. As Wright observed in a prescient lecture to the National Parks Association in Canberra in 1968, 'we must regenerate ourselves if we are to regenerate the earth,' and for that to occur, '[o]ur feelings and emotions must be engaged, and engaged on a large scale' (Because 206). ${ }^{15}$ To break through the silence imposed by the standpoint of mastery we need to attend to the poetic voice of ecoprophets such as Judith Wright. She might have had poor hearing: but to a greater extent than any other major Australian writer of her generation, Wright had an ear for the cry of the oppressed, human and otherwise. Responding to that cry in poems such as 'Dust,' she calls her readers to mourn with and for the land and its diverse denizens. Such grief alone has the capacity to bring down the walls of human self-enclosure that render us insouciant towards other-than-human suffering, and, in so doing, open the flood-gates of justice and compassion. For, as Glenda Cloughley writes in 'The Gifts of the Furies', a contemporary choral work of ecoprophetic witness that premiered in Canberra on 29 March 2009, 'lament is the start of renewal' ${ }^{16}$

The challenge for writing in the anthropocene, in the shadow of ecocide, then, is to find new ways of raising our voices from the level of 'idle chatter' to that of biting and stinging ecoprophetic witness. For unless we can hear Earth's cry and respond with the kind of grief that energizes just and compassionate action, in recognition of our own complicity in a wrong that now imperils us all, there will be in the future no land, anywhere, in which 'our son's sons may harvest and be fed'.

15 This talk was subsequently published by the Australian Conservation Foundation under the title 'Conservation as an Emerging Concept'. I am grateful to Don Henry, current Executive Director of the ACF, who cited this essay in his talk at the 2009 Two Fires Festival.

16 A recording of the premiere performances of 'The Gifts of the Furies' has since been released on DVD and is available for purchase from the Chorus of Women via their website: http://www.chorusofwomen.org/ 
Kate Rigby is an Associate Professor in the Centre for Comparative Literature and Cultural Studies at Monash University and a Fellow of the Australian Academy of the Humanities. She was the founding President of ASLE-ANZ and her most recent book is Topographies of the Sacred: The Poetics of Place in European Romanticism (University of Virginia Press, 2004).

\section{Works Cited}

Adorno, Theodor. Aesthetic Theory. Trans. C. Lenhardt. Ed. Gretel Adorno and Rolf Tiedemann. London and New York: Routledge and Kegan Paul, 1984.

-. Beethoven: Philosophie der neuen Musik. Vol. 1 of Nachgelassene Schriften, ed. Rolf Tiedemann. Frankfurt a.M.: Suhrkamp, 1993.

—. Prisms. Trans. Samuel and Shierry Weber. Cambridge, Mass.: MIT Press, 1981.

- Problems of Moral Philosophy. Ed. Thomas Schröder. Trans. Rodney Livingstone. Stanford: Stanford UP, 2000.

Bennett, Bruce. An Australian Compass: Essays on Place and Direction in Australian Literature. Fremantle: Fremantle Arts Centre, 1999.

Benso, Sylvia. The Face of Things: A Different Side of Ethics. Albany: SUNY, 2000.

Blanke, Christa. Da krähte der Hahn: Kirche für Tier? Eine Streitschrift. Eschbach, Germany: Verlag am Eschbach, 1995.

Brady, Veronica. South of My Days. A Biography of Judith Wright. Sydney: HarperCollins, 1998.

- ' 'What are Writers for in a Destitute Time? Judith Wright and the Search for Australia.' LocalGlobal. Identity, Security, Community 3 (2007): 12-18.

Brueggeman, Walter. The Prophetic Imagination, 2nd ed. Minneapolis: Fortress Press, 2001.

Buber, Martin. 'Prophecy, Apocalyptic, and the Historical Hour.' In Pointing the Way. Collected Essays. Trans. Maurice Friedman. London: Routledge and Kegan Paul, 1957. 192-208.

Derrida, Jacques. The Animal That Therefore I Am. Ed. Marie-Louise Mallet. Trans. David Wills. New York: Fordham University Press, 2008. 
Eagleton, Terry. After Theory. London: Penguin, 2004.

Gerhard, Christina. 'The Ethics of Animals in Adorno and Kafka.' New German Critique 33.1 (2006):159-178.

Gifford, Terry. 'Climate Change and Judith Wright's Post-pastoral Poetry.' Forthcoming in Australian Humanities Review 2010.

Green Bible, The. New Revised Standard Version. New York: HarperCollins, 2008.

Heschel, Abraham J. The Prophets, vol. 1. New York: Harper and Row, 1962.

Holy Bible, The. Authorised King James Version. Oxford: Oxford UP, no date.

Kafka, Franz. Briefe 1900-1912. Ed. Hans-Gerd Koch. Frankfurt a.M.: S. Fischer, 1999.

Kohn, Jenny. 'Longing to Belong: Judith Wright's Poetics of Place.' Colloquy 12 (2006): 114-26.

Kutchins, Laurie. 'A Wild Sound, Wild Wound: Some Thoughts on Judith Wright.' LocalGlobal. Identity, Security, Community 3 (2007): 42-51.

Martin, Elaine. 'Re-reading Adorno: The "after Auschwitz" Aporia,' Forum 2 (Spring 2006). http://forum.llc.ed.ac.uk/issue2/martin.pdf Accessed 28 September 2009.

Oliver, Mary. Blue Iris: Poems and Essays. Boston: Beacon Press, 2004.

Plumwood, Val. Feminism and the Mastery of Nature. London: Routledge, 1993.

- . "Nature as agency and the prospects for a progressive naturalism," Capitalism, Nature, Socialism 12:4 (Dec. 2001), 3-32.

- Environmental Culture. The Ecological Crisis of Reason. London: Routledge, 2002.

Rees, Stuart. 'Can Poets Change the World?' LocalGlobal. Identity, Security, Community 3 (2007): 33-41.

Rigby, Kate. 'Earth, World, Text: On the (Im)possibility of Ecopoiesis.' New Literary History 35.3 (2004): 427-42.

-. 'Writing After Nature,' Australian Humanities Review, Issue 39-40 (2006). http://www.australianhumanitiesreview.org/archive/Issue-September-2006/ rigby.html Accessed 28 September 2009.

Robin, Libby. 'Battling the Land and Global Anxiety: Science, Environment and Identity in Australia.' Forthcoming in Philosophy Activism Nature (2009). 
Roelvink, Gerda and Gibson-Graham, J.K. 'A Post-Capitalist Politics of Dwelling: Ecological Humanities and Community Economies in Conversation.' Australian Humanities Review, Issue 46 (2009). http://epress.anu.edu.au/ ahr/046/pdf/eh05.pdf Accessed 28 September 2009.

Rose, Deborah Bird. Reports from a Wild Country. Ethics for Decolonisation. Sydney: UNSWP, 2004.

—.'On history, trees, and ethical proximity.' Postcolonial Studies, 11.2 (2008): 157-167.

Savage, Robert. 'Adorno's Family and Other Animals.' Thesis Eleven 78 (2004): 102-12.

Schmidt, Laurie J. 'When the Dust Settles.' NASA Earth Observatory, 18 May 2001. http://earthobservatory.nasa.gov/Features/Dust/ Accessed 28 September 2009.

Sharp, Nonie. 'A Poet's Feeling for the Earth.' LocalGlobal. Identity, Security, Community 3 (2007): 24-32.

Steiner, George. Language and Silence: Essays on Language, Literature and the Inhuman. London: Yale UP, 1970.

Wright, Judith. Because I was Invited. Melbourne: Oxford UP, 1975.

-. The Cry of the Dead. Carlton: Melbourne UP, 1981.

-. Born of Conquerors. Selected Essays. Canberra: Aboriginal Studies P, 1991.

—. Collected Poems. Sydney: HarperCollins, 1994. 